\title{
BELTING, Hans, Die Deutschen und ihre Kunst, ein schwieriges Erbe
}

Thierry Nadau

\section{OpenEdition}

Journals

Édition électronique

URL : http://journals.openedition.org/ifha/2037

DOI : $10.4000 /$ ifha. 2037

ISSN : 2198-8943

\section{Éditeur}

IFRA - Institut franco-allemand (sciences historiques et sociales)

Référence électronique

Thierry Nadau, "BELTING, Hans, Die Deutschen und ihre Kunst, ein schwieriges Erbe », Revue de l'IFHA [En ligne], Date de recension, mis en ligne le 01 janvier 1994, consulté le 22 septembre 2020. URL : http:// journals.openedition.org/ifha/2037 ; DOI : https://doi.org/10.4000/ifha.2037

Ce document a été généré automatiquement le 22 septembre 2020

(CIFHA 


\section{BELTING, Hans, Die Deutschen und ihre Kunst, ein schwieriges Erbe}

\section{Thierry Nadau}

Les Allemands et l'art, un thème oublié car focalisé exclusivement sur la question de l'art pendant le IIIe Reich ou de son statut dans la République Démocratique Allemande. Pris ainsi, l'art est d'abord un héritage lourd à porter, aux connotations négatives, mettant en avant les efforts désespérés d'une minorité dans sa lutte contre le « système ", c'est-à-dire tout de même contre la « majorité ». Il semble intéressant dans cette perspective à H.B. de se focaliser sur la période de l'Empire où l'art est très fortement socialisé, et ce dans un cadre qui n'est pas systématiquement répressif. Il s'agit ici aussi de réagir contre une histoire de l'art qui, après la Seconde Guerre mondiale, a très nettement mis de côté les aspects d'insertion sociale et vu l'art comme une production dont le contexte était international.

Thierry NADAU 